\author{
Aleksandra SOJKA \\ University of Granada, Spain \\ sojka@ugr.es
}

\title{
UNCONDITIONAL SUPPORT?
}

\author{
EURO-CRISIS AND INSTITUTIONAL TRUST \\ IN CENTRAL-EASTERN EUROPE ${ }^{1}$
}

ABSTRACT European Union (EU) membership constituted an important element for the stabilization and modernization of democratic institutions in post-1989 Central-Eastern Europe (CEE). While public opinion support for European integration has not been uniform in the region, trust in European institutions has been consistently higher than confidence in domestic institutions in the region. EU structures and policies have been often perceived as necessary and efficient, especially where domestic institutions were failing. However, the financial and economic crisis of the first decade of the $21^{\text {st }}$ century has seriously undermined such perceptions of output legitimacy of EU institutions and, consequently, support for the European integration project and trust in supranational institutions has been eroding in the whole of the EU. In this context, the goal of the article is to explore the possible link between CEE citizens' evaluations of the financial, economic, and political crisis within the EU and their institutional trust in a multilevel political system.

Keywords: institutional trust, economic crisis, Central Eastern Europe, European Union

Earlier drafts of this article have been presented and discussed at the ECPR Joint Sessions in Mainz (March 2013) and the EPSA Conference in Barcelona (June 2013). I am grateful for all the comments and remarks received from the participants of both seminars. 


\section{INTRODUCTION}

Over a decade after the "Big Bang" Eastward enlargement, we can now start to assess the way in which attitudes of the new European citizens from Central and Eastern Europe have developed in the context of their EU membership. Some of the recent studies of support for integration in this group of countries point to the economic benefits as most important explanatory variable of support after accession, ${ }^{2}$ while other explain differences between countries in relation to the satisfaction with the workings of national democracy. ${ }^{3}$ Both factors could be potentially relevant to changes in attitudes which had occurred as consequences of the financial and economic crisis of the first decade of the $21^{\text {st }}$ century. These recent developments severely undermined the legitimacy of the EU institutions and eroded support for the European integration project in most of the member states.

If the economic benefits drive attitudes towards the EU in Central Eastern Europe, the impact of the economic crisis could constitute a decisive factor in the decline of trust in European institutions in the region. However, it stems from the existing research that economic calculations are not the only relevant factor which conditions political attitudes. We must also take into account how attitudes are shaped by perceptions of political and economic performance. Specifically, in the context of Central and Eastern Europe, EU membership has been considered as a guarantee for the modernization and stabilization of the recently re/established democratic institutions and the functioning of market economy. This implied a general positive image of the EU which fostered "unconditional support" for integration ${ }^{4}$ and high levels of trust in EU institutions.

While trust in European institutions has been high, political trust in domestic institutions, on the other hand, has been generally low, a situation considered to be a legacy of non-democratic regimes in the region. ${ }^{5}$ In the context of the EU, discontent with performance of domestic institutions has been argued to constitute a central element to the support for European integration and attitudes towards EU institutions. ${ }^{6}$

2 J.E. Jackson, B.W. Mach, J.L. Miller-Gonzalez, 'Buying Support and Regime Change: The Evolution of Polish Attitudes towards the EU and Voting between Accession and 2008', European Union Politics, Vol. 12, No. 2 (2011), at <http://dx.doi.org/10.1177/1465116511400197>.

3 G. Ilonszki, 'National Discontent and EU Support in Central and Eastern Europe', Europe-Asia Studies, Vol. 61, No. 6 (2009), at <http://dx.doi.org/10.1080/09668130903063591>.

4 S. Guerra, 'Does Familiarity Breed Contempt? Determinants of Public Support for European Integration and Opposition to It before and after Accession', Journal of Common Market Studies, Vol. 51, No. 1 (2013), at <http://dx.doi.org/10.1111/j.1468-5965.2012.02300.x>.

5 W. Mishler, R. Rose, 'Trust, Distrust and Skepticism: Popular Evaluations of Civil and Political Institutions in Post-Communist Societies', The Journal of Politics, Vol. 59, No. 2 (1997), at <http://dx.doi. org/10.2307/2998171>

6 I. Sánchez-Cuenca, 'The Political Basis of Support for European Integration', European Union Politics, Vol. 1, No. 2 (2000), at <http://dx.doi.org/10.1177/1465116500001002001 >; G. Ilonszki, 'National Discontent...'; J. Muñoz, M. Torcal, E. Bonet, 'Institutional Trust and Multilevel Government in 
From this perspective, perceptions of political and economic performance of institutions (national and supranational) are directly linked. The underlying assumption to these approaches has been the perception of the $\mathrm{EU}$ as an efficient alternative to the low-performing national institutions.

Another key element to understand how EU attitudes are shaped is the general low level of knowledge about the workings of the rather remote European institutions, which results in the use of national proxies ${ }^{7}$ to evaluate the EU. However, in the current context of financial crisis and the intense media coverage of the austerity measures promoted by the EU to resolve the economic problems, difficulties related to the working of the EU institutions have become more visible, possibly influencing both assumptions. As we take this fact as our starting point, the goal is to investigate the link between citizens' perceptions of the EU performance and its crisis, and their attitudes towards the political system. In other words, we seek to verify whether in the new member states, where the EU has been perceived mainly through its economic outputs and membership has been predominantly conceived as an opportunity for further institutional modernization, the current context of EU financial, economic, and institutional crisis has had an impact on trust in supranational and national institutions.

The article is structured into three parts: firstly, the theoretical underpinnings of studying institutional support and political trust in a multilevel system of governance in general, and in the context of Central Eastern Europe in particular are briefly presented. Secondly, we explore the patterns of trust in European and national institutions across Central-Eastern Europe and present some contextual variables which depict the impact of the crisis on the economies of the new member states, together with citizens' perceptions of the economy. Finally, logistic regression models are proposed in order to verify to what extent the perceptions of economic crisis and EU performance could constitute explanatory factors of trust in domestic and European institutions in Central-Eastern Europe.

\section{TRUST IN NATIONAL AND SUPRANATIONAL INSTITUTIONS: THEORETICAL OUTLINE}

The structure and development of public opinion attitudes towards the EU are well documented in the case of the EU-15, providing us with concrete explanatory models pointing, among others, to instrumental factors, ${ }^{8}$ national proxies, ${ }^{9}$ the effects of

the European Union: Congruence or Compensation?', European Union Politics, Vol. 12, No. 4 (2011), at <http://dx.doi.org/10.1177/1465116511419250>.

7 Ch.J. Anderson, 'When in Doubt, Use Proxies: Attitudes toward Domestic Politics and Support for European Integration', Comparative Political Studies, Vol. 31, No. 5 (1998), at <http://dx.doi.org/10. 1177/0010414098031005002>.

8 M. Gabel, 'Public Support for European Integration: An Empirical Test of Five Theories', The Journal of Politics, Vol. 60, No. 2 (1998).

9 Ch.J. Anderson, 'When in Doubt...' 
cognitive mobilization, ${ }^{10}$ political cueing, ${ }^{11}$ performance of institutions ${ }^{12}$ and affective/ identity factors. ${ }^{13}$ However, since our main point of interest lies in the possible relationship between the supranational and the national level of governance, in what follows we focus on the instrumental and performance theories regarding support for political system in European Union and how the connection between political trust and the performance of institutions could be theoretically formulated from the perspective of Central Eastern European member states.

As a result of its progressive politicization, the subjective legitimacy of the EU that is, legitimacy rooted in citizens' beliefs ${ }^{14}$ - has become an issue of intense academic debate, reflected in the growing number of publications on this topic. ${ }^{15}$ Political support is central to these debates, and one of the most influential approaches to this issue has been formulated already in the 1960's when Easton put forward his model for the analysis of political systems with concepts of support and legitimacy as central to it. ${ }^{16}$ If we treat the EU as a political system, ${ }^{17}$ one of the biggest challenges is to consider how institutions at different levels (national and supranational) interact with each other and how we can conceptualize these interactions within a multilevel structure of government within the analytical framework of political support and to pay attention to the interplay of support among different levels of government. ${ }^{18}$

Initially the theories concerning support for the EU focused on utilitarian factors. The instrumental approach rests on the assumption that economic conditions influence support for the EU and citizens make rational calculations about the benefits

10 R. Inglehart, 'Cognitive Mobilization and European Identity', Comparative Politics, Vol. 3, No. 1 (1970), at <http://dx.doi.org/10.2307/421501>.

11 L. Hooghe, G. Marks, 'Calculation, Community and Cues: Public Opinion on European Integration', European Union Politics, Vol. 6, No. 4 (2005), at <http://dx.doi.org/10.1177/ $1465116505057816>$.

12 I. Sánchez-Cuenca, ‘The Political Basis...; G. Ilonszki, 'National Discontent...’; J. Muñoz, M. Torcal, E. Bonet, 'Institutional Trust...'

13 L.M. McLaren, Identity, Interests, and Attitudes to European Integration, Basingstoke 2006 (Palgrave Studies in European Union Politics); S. Duchesne, A.-P. Frognier, 'National and European Identifications: A Dual Relationship', Comparative European Politics, Vol. 6, No. 2 (2008), at <http://dx.doi. org/10.1057/palgrave.cep.6110128>.

14 D. Fuchs, 'European Identity and Support for European Integration' in S. Lucarelli, F. Cerutti, V.A. Schmidt (eds.), Debating Political Identity and Legitimacy in the European Union, AbingdonNew York 2011 (Routledge/Garnet Series. Europe in the World, 11).

15 S. Lucarelli, F. Cerutti, V.A. Schmidt (eds.), Debating Political Identity...; V.A. Schmidt, 'The Problems of Identity and Legitimacy in the European Union. Is More Politics the Answer?' in S. Lucarelli, F. Cerutti, V.A. Schmidt (eds.), Debating Political Identity...; D. Fuchs, H.-D. Klingemann, (eds.), Cultural Diversity, European Identity and the Legitimacy of the EU, Cheltenham 2011 (Studies in EU Reform and Enlargement), among others)

16 D. Easton, A Systems Analysis of Political Life, Chicago 1979 (Political Theory, 833).

17 S. Hix, B. Høyland, The Political System of the European Union, Basingstoke 2011 (The European Union Series).

18 J. Muñoz, M. Torcal, E. Bonet, 'Institutional Trust..., p. 552. 
from European integration. ${ }^{19}$ However, these explanatory models have been soon supplemented by other theories which related support for EU membership to other types of factors. Specifically, here the model proposed by Anderson ${ }^{20}$ is of interest as he connects the national and the European level by arguing that due to the fact that citizens are generally ill-informed about the workings of the EU, their attitudes towards the supranational level are not the result of a rational cost-benefit calculation regarding European integration, rather their support for the EU is mediated by their perception of domestic politics. Specifically, he demonstrates that citizens' diffuse support of the domestic political system (operationalized as satisfaction with the way national democracy works) constitutes a proxy for attitudes towards EU membership. More recently, Sánchez Cuenca ${ }^{21}$ disputes such view and argues, quite to the contrary, that citizens are in fact capable of discerning between the two levels of institutions and that the worse citizens' opinion of national institutions and the better the opinion of supranational ones, the stronger the support for European integration. ${ }^{22}$ Muñoz et al. ${ }^{23}$ try to reconcile both perspectives by arguing for a congruence/compensation model taking the example of national parliaments and the EP. Their argument follows the assumption that in a multilevel political system such as the EU, there are different effects of trust in institutions at different levels. Therefore, at the individual level, institutional trust spills over onto different levels of government, and therefore trustworthiness is congruent. ${ }^{24}$ However, at the country level, a compensatory process is in place - citizens who live in countries with general low levels of political trust (and poorly performing institutions) tend to have higher trust in EU institutions.

While most previous research explored the mediating role of the national political arena on European trust, in the context of the current institutional crisis of the EU, we must also ask whether and how the perceptions of the economic and political difficulties in tackling of the crisis by EU institutions impact attitudes towards domestic and European institutions. In the remaining part of the article, we address this question for the case of Central and Eastern European EU member states.

\section{POLITICAL TRUST IN CENTRAL EASTERN EUROPE: A LEGACY OF UNTRUSTWORTHINESS?}

When assessing the effects of Eastward enlargement of the EU, some authors suggest that the new member states of Central Europe differ from the previously admitted members in terms of political attitudes due to their differential socialization processes

\footnotetext{
19 M. Gabel, 'Public Support...'

20 Ch.J. Anderson, 'When in Doubt...'

21 I. Sánchez Cuenca, 'The Political Basis...'

22 Ibid., p. 169.

23 J. Muñoz, M. Torcal, E. Bonet, 'Institutional Trust...'

24 Ibid., p. 552.
} 
and historical experience following the Second World War. ${ }^{25}$ Much of the debate concerning the Eastward enlargement of the EU has been accompanied by a concern that citizens of Central and Eastern European countries, may remain more attached to their recently regained national sovereignty, and exhibit higher levels of Euroscepticism. ${ }^{26}$ Some authors even argue that the enlargement has had negative effects on the sense of community within the EU, as the new member states exhibit lower levels of trust in other people ${ }^{27}$ and a tendency to distrust political institutions. ${ }^{28}$

Indeed the CEE countries share important historical legacies, as well as recent experiences of profound economic, political and societal change. However, there are also significant divergences in their histories and polities prior to and during the imposition of socialist regimes which constitute important legacies and sources of differential present-day institutional and economic performance. ${ }^{29}$ Moreover, there is also much heterogeneity between the ten countries of Central and Eastern Europe in terms of their trajectories and economic and political performance following 1989, as well as in their accession processes and performances as EU members. ${ }^{30}$ Therefore, our aim is not to suggest that by treating them jointly as the "new EU member states", we are dealing with a homogenous group. The element which connects the CEE member states is their situation as newcomers to the EU and the status of their people as "new European citizens".

From the perspective of Central Eastern European member states - young democracies with legacies of non-democratic regimes - the generally low levels of political trust have been linked to political and economic performance as mediated by individual perceptions and attitudes. ${ }^{31} \mathrm{EU}$ accession encapsulated the promise of improving the economic well-being of its new citizens. Moreover, in Central Eastern European member states EU integration represented a promise of improvement of personal economic situation and the national economy, as well as a guarantee for the stability of democratic

25 D. Fuchs, H.-D. Klingeman, 'Democratic Communities in Europe. A Comparison between East and West' in H.-D. Klingemann, D. Fuchs, J. Zielonka (eds.), Democracy and Political Culture in Eastern Europe, London 2006 (Routledge Research in Comparative Politics, 15).

26 Cf. Z. Mach, G. Pożarlik, Collective Identity Formation in the Process of EU Enlargement. Defeating the Inclusive Paradigm of a European Democracy?, Oslo 2008 (RECON Online Working Paper, 14). D. Fuchs, H.-D. Klingeman, 'Democratic Communities in Europe...'

W. Mishler, R. Rose, 'Trust, Distrust and Skepticism...'

There is a rich scholarship exploring the sources and consequences of these dissimilarities in post-socialist CEE (JJ. Linz, A.C. Stepan, Problems of Democratic Transition and Consolidation. Southern Europe, South America, and Post-Communist Europe, Baltimore 1996; C. Offe, The Varieties of Transition. The East European and East German Experience, Oxford 1996; M.A. Vachudová, Europe Undivided. Democracy, Leverage, and Integration after Communism, Oxford 2005; S. Ramet (ed.), Central and Southeast European Politics since 1989, Cambridge-New York 2010; S. White, J. Batt, P.G. Lewis (eds.), Developments in Central and East European Politics, 5, Basingstoke 2013, among others), a summary of which is beyond the scope of this article.

31 W. Mishler, R. Rose, 'What Are the Origins of Political Trust?: Testing Institutional and Cultural Theories in Post-Communist Societies', Comparative Political Studies, Vol. 34, No. 1 (2001), p. 55, at $<$ http://dx.doi.org/10.1177/0010414001034001002>. 
institutions. These expectations favored the emergence of a positive idea of the EU linked to "unconditional support". ${ }^{32}$ In terms of the institutional theory, national trustworthiness standard ${ }^{33}$ and the perception of economic and political performance of national institutions have been lower in CEE than that in the rest of the EU countries, while support for European integration and trust in EU institutions have been high, in line with the compensation hypothesis.

However, EU membership is no longer a possibility which might be supported or opposed on the basis of utilitarian calculations or evaluations concerning the future. Citizens of the new member states are already part of the EU and as such can develop more sophisticated and nuanced assessments of what their countries' membership in the EU $m_{e a n s^{34}}$ and become more realistic about the gains to be expected from integration. Direct experience of membership together with worsening perceptions of EU output performance should have an impact on attitudes in these new member states. This is why it becomes of interest here to investigate the relationship between the declining support for EU and trust in European and domestic institutions in CEE countries.

\section{HYPOTHESES AND DATA}

In a multilevel system of governance, such as the European Union, the objects of political trust are multiplied as national and supranational institutions become linked. So far, the main preoccupation in EU scholarship has been to establish the sources of trust in supranational institutions, where the performance of national institutions and perceptions of economic situation constituted principal explanatory factors. ${ }^{35}$

As we approach the EU as a political system, where the national and the supranational levels influence each other, it can be assumed that citizens' perceptions of the political and economic crisis at the supranational level are correlated with their attitudes not only towards the supranational institutions, but also, towards the domestic political system. It could be that citizens of the new member states, who no longer perceive the EU as the panacea for their problems, could turn to their national institutions. However, it is also possible that since the national political institutions might be perceived as part of the bigger supranational system of decision-making where the democratic deficit becomes more and more visible, citizens might feel excluded and, thus, loose trust in both levels of governance.

In order to test both possibilities, in what follows we present a comparative study of the patterns of trust in European and national institutions in the new member states

32 S. Guerra, 'Does Familiarity Breed Contempt?..., p. 10.

33 J. Muñoz, M. Torcal, E. Bonet, 'Institutional Trust...'

34 M. Loveless, 'Agreeing in Principle: Utilitarianism and Economic Values as Support for the European Union in Central and Eastern Europe', Journal of Common Market Studies, Vol. 48, No. 4 (2010), p. 1098, at <http://dx.doi.org/10.1111/j.1468-5965.2010.02088.x>.

35 I. Sánchez-Cuenca, 'The Political Basis...; G. Ilonszki, 'National Discontent...'; J. Muñoz, M. Torcal, E. Bonet, 'Institutional Trust....' 
of the EU. Moreover, we verify whether the perceptions of economic crisis at the European level and EU's problems in its management could constitute a factor which correlates with higher levels of trust in the domestic political institutions. Specifically, we test hypotheses regarding the effect of the declining perceptions of economic and political performance of the EU on political trust in Central Eastern Europe. One set of hypotheses relates to the performance of national and European economies. Our first hypothesis is that negative perceptions of national economy might foster more trust in the $E U$, in line with the expectations regarding modernization and development of the new EU member states (H1.a). The second one is that the perceptions of economic problems at the European level might erode the image of the EU's effectiveness and increase the odds of trusting in national parliament (H1.b). The second set of hypotheses, relates to the interplay of political trust between the two levels of government. Based on the congruence assumption, we posit that individual low levels of trust are part of a more generalized disaffection with the political system and as such trust in national (H2.a) and supranational institutions $(\mathrm{H} 2 . \mathrm{b})$ will be correlated.

We have used the data available from recent Eurobarometer (EB) studies to test the above hypotheses concerning political trust at the national and European level. Three recent EB studies have been chosen to illustrate the trends in institutional trust over the last decade. The first selected study is EB 62, from autumn 2004, just after the first Eastward enlargement of May 2004. Latecomers Romania and Bulgaria are also included in the group of Central and Eastern European member states, even though these two countries became members of the EU only in 2007. However, after inspecting country levels of institutional trust in both countries the results are similar to the rest of CEE member states. The second time point examined is 2008, particularly EB 69.2 with fieldwork developed in spring 2008, a few months before the bankruptcy of Lehman Brothers which marks the initial point of the global economic crisis. The third time point selected for comparison is a more recent Eurobarometer study which includes trust variables, from autumn 2011 (EB 76.3), where we can be sure that the impact of the economic crisis in general and the problems of the Eurozone in particular can be evaluated. This selection provides a good basis for comparisons of the evolution of political trust in all EU countries, allowing for an assessment of the impact of such a recent development as the economic and financial crisis. ${ }^{36}$

There are nevertheless some issues with the chosen data source. Most importantly, the institutional trust question in the Eurobarometer series is formulated in a dichotomous way - respondents can indicate only whether they "tend to trust" or "tend not to trust". Such a formulation is clearly very limiting, as it does not allow us to establish the intensity of institutional trust (in contrast to other cross-national surveys, such as the EVS, IntUne). However, other studies which do include more sensitive measures of our dependent variable, offer limited time perspective on the impact of the economic crisis

36 The data selected excludes the possibility of considering the eleventh CEE EU member state - Croatia. Therefore, the article focuses on the ten Central and Eastern European member states which joined the EU in 2004 and 2007 (CEE-10). 
which broke out just as the last available surveys were carried out (2008 for EVS and 2009 for the IntUne data).

\section{TRUST AND ECONOMIC CRISIS IN CENTRAL EASTERN EUROPE: INDICATORS AND PERCEPTIONS}

The ten new member states of Central Eastern Europe exhibited important differences to the old member states of the EU at the moment of accession in terms of their economic development. One good indicator of this difference is GDP per capita, as compared to the level of the whole of the EU-27. We can get a good idea of the gap in economic prosperity between the two groups of countries by a comparison of GDP per capita in the newly admitted member states and the old members (EU-15). We can observe the difference between the two groups, as well as the unequal levels of economic prosperity within the CEE region itself in figure 1.

Figure 1. GDP in Central and Eastern European EU member states (2004-2012)

GDP

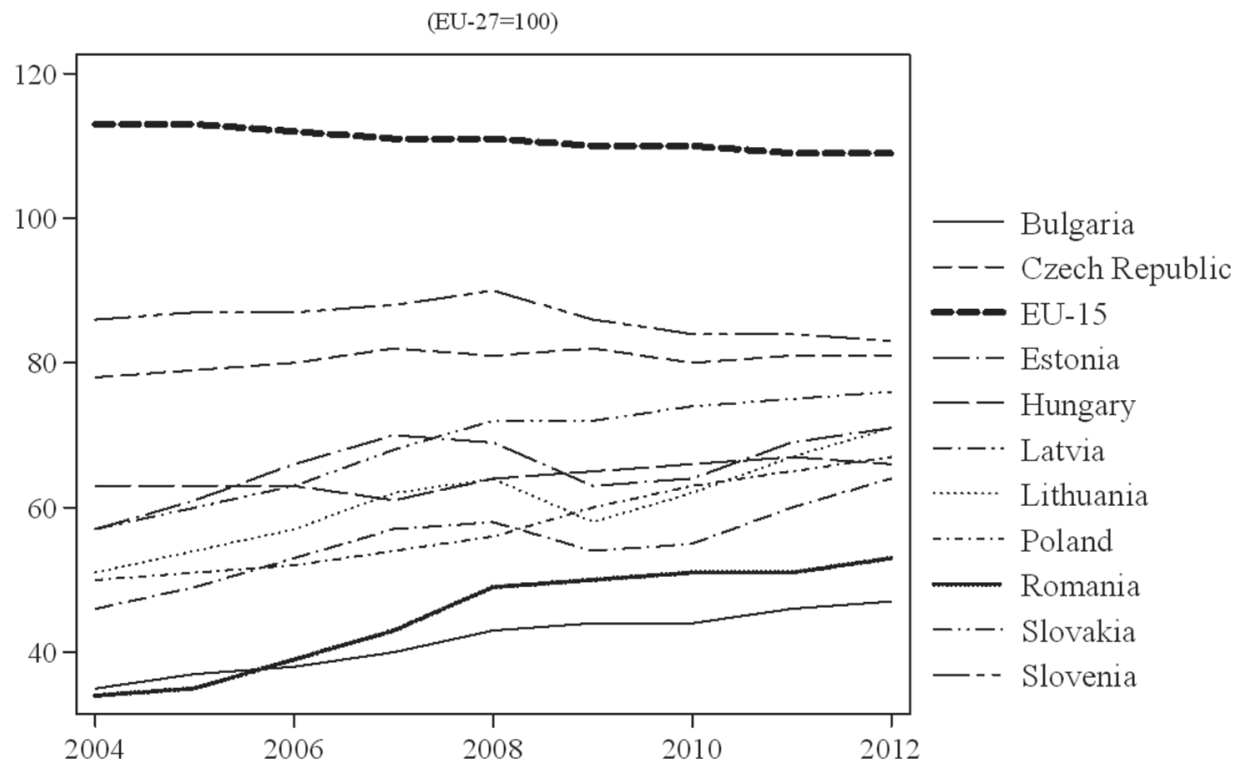

Note: EU27=100. Data: Eurostat.

With the first wave of CEE accession (2004) the average GDP per capita of the CEE-10 countries represented only half of that of Western Europe (EU-15). Thanks to high levels of GDP growth in the initial years of membership at least partially driven by the economic facilities of single market and substantial fiscal transfers from the EU - 
via its regional and cohesion, as well as agricultural policies - this difference diminished slightly over the course of the first decade of membership. Admittedly, such general division between old and new member states in terms of economic prosperity obscures important variation among CEE countries. While Slovenia and Czech Republic have been closer to the EU-27 average than the rest of the CEE-10 countries from the start, and their GDP has not varied greatly, others were much worse-off initially and many experienced a strong improvement in their economies following accession. Particularly, Romania's and Bulgaria’s GDP per capita represented only $30 \%$ of EU's average GDP in $2004,40 \%$ at the moment of their delayed accession (2007) and it reached the level of $50 \%$ of EU's average by 2012.

Overall, the progress has been most pronounced in Lithuania, Slovakia, and Latvia where GDP per capita rose in almost 20 points after 2004 (in terms of the EU-27 average) but significant disparities in levels of economic development still persist. Hungary is a noteworthy case, as GDP per capita of Hungarians almost did not vary over the years, which resulted in the loss of its position as one of the frontrunners of CEE-10 in economic terms, as other countries experienced far greater economic improvements after accession. Overall, while significant differences persist among the CEE-10 countries, the relative economic poverty of these countries constitutes a central factor to be taken into account when analyzing patterns of $\mathrm{EU}$ attitudes, ${ }^{37}$ a factor which becomes especially relevant after accession..$^{38}$

While the 2004-2007 Eastern enlargement constituted an unprecedented challenge to the European Union, soon enough another, even greater challenge arose. The onset of the global financial crisis and the ensuing recession, followed by the banking and sovereign debt crises in several EU member states have painfully highlighted the flaws inherent in the setup of the Economic and Monetary Union (EMU). The political inability of European leaders to efficiently tackle the problems, and the austerity measures which followed, proved to be a ripe ground for populism and a growing popular and party-based Euroscepticism, ${ }^{39}$ even in countries such as Germany, where questioning the foundations of European integrations was until recently unthinkable.

Whereas problems in the periphery of the old member states focused most of the attention on the coverage of the European branch of the crisis, new member states also paid a high price for choosing the Western economic model. As the graph below illustrates, GDP growth in the CEE EU member states after the 2004 enlargement has been steadily higher than the average of the EU-15, contributing to a closing of the gap in GDP between new and old member states. However, after experiencing several years of

37 J. Garry, J. Tilley, 'Public Support for Integration in the Newly Enlarged EU: Exploring Differences Between Former Communist Countries and Established Member States' in M. Marsh, S. Mikhaylov, H. Schmitt (eds.), European Elections after Eastern Enlargement. Preliminary Results from the European Election Study 2004, Mannheim 2007 (CONNEX Raport Series, 01).

39 F. Serricchio, M. Tsakatika, L. Quaglia, 'Euroscepticism and the Global Financial Crisis', Journal of Common Market Studies, Vol. 51, No. 1 (2013), at <http://dx.do.org/10.1111/j.1468-5965. 2012.02299.x>. 
economic boom, when the financial crisis made its mark on European economies, recessions hit the CEE economies harder than most of the old member states (see Figure 2 ) and further divisions emerged between these countries.

Figure 2. GDP growth (2004-2012)

\section{GDP Growth}

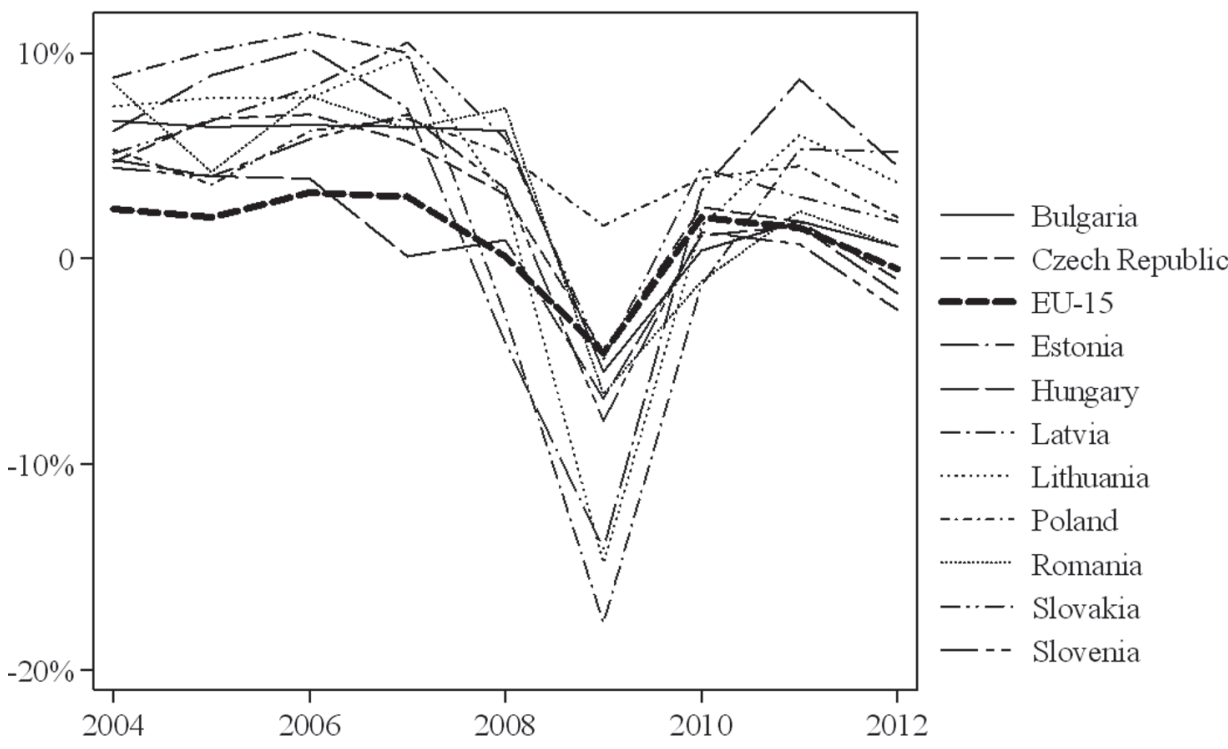

Note: The graph represents percentage change over previous period. Data: Eurostat.

Poland is the only EU economy which managed to avoid recession at the end of the first decade of the $21^{\text {st }}$ century. The Baltic countries, on the other hand, have deeply suffered the disadvantages of deregulated capitalism. As early as 2008-2009, these champions of neoliberal market policies experienced profound recessions, managing to overcome the problems relatively quickly by implementing even more reforms.. Moreover, countries such as Romania and Hungary continue to suffer from a combination of slower change with erroneous policy choices and both had to apply for financial assistance from the EU and the IMF, when the global economic downturn struck Europe. Overall, as Connolly remarks, with the exception of Poland, the region suffered a more severe reversal of pre-crisis output trends than any other region of the world economy. ${ }^{40}$

Problems in the periphery of the Eurozone also affected the CEE-10 countries more directly. Slovakia, for instance, as a Eurozone member, was one of the countries which contributed to the first bailout of Greece. This caused a severe government crisis and

40 R. Connolly, 'The Determinants of the Economic Crisis in Post-Socialist Europe', Europe-Asia Studies, Vol. 64, No. 1 (2012), p. 64, at <http://dx.doi.org/10.1080/09668136.2012.635474>. 
public opinion uproar, as it was portrayed in the media as the poor Slovakspaying for the rich Greeks. ${ }^{41}$ Thus, just a few years after becoming EU members, as a result of the global financial crisis, the downside of capitalist system embedded in a global economic order was revealed in CEE-10 countries ${ }^{42}$ and some of the previously established roles within the European community have been inverted. Problems did not come from the new member states, rather from the heart of the pre-existing institutional setup and longer-established members. In the crisis, the CEE countries were "green islands" (Poland), champions of reform (the Baltic states) and even contributors to the rescue funds constituted to save some of the most troubled EU members (Slovakia, and the rest of the CEE countries which adopted euro as their currency in the recent years).

How are these macroeconomic changes reflected in the public perceptions of economy? Using the Eurobarometer survey of 2011, we can compare the share of respondents who indicate a negative view of national and European economy. In order to make the comparison easy to interpret the EU countries are grouped. However, instead of comparing the CEE countries to the EU-15, we decided to divide the old member states into two groups. EU-5 refers to the old member states most severely affected by the Eurocrisis (Portugal, Ireland, Italy, Greece, and Spain) and EU-10 refers to the rest of the EU countries, members before 2004. Here the main point of interest is to explore the changes in political trust in relation to the economic crisis, and therefore it makes sense to group Southern European new democracies together with Ireland and Italy, as all five states most hardly affected by the sovereign debt crisis and austerity measures implemented within the EU to tackle it. Since the main objective is to evaluate the way institutional trust changed in the group of Central and Eastern European states, the two other new member states which do not belong to this category, Cyprus and Malta, are excluded from the comparison.

We can see that in the five countries (EU-5) most severely affected by the economic and financial crisis both the perception of national, as well a European economy are very negative (more than 90\%), while in the other ten old member states of Western Europe the perception of European economy is rather negative, while that of national economy is much better. The CEE member states are somewhere in the middle. Latvia and Lithuania and the latecomers, Romania and Bulgaria, evaluate the European economy much better than their national economy. Polish respondents are the least negative both in terms of their perceptions of the national, as well as the European economic developments. In the Czech Republic and Slovakia the perception of both levels is almost equal-

41 'Slovakia's Revolt against Solidarity', The Economist, 14 August 2010, at <http://www.economist. com/blogs/easternapproaches/2010/08/slovakia_and_greece>.

42 H.W. Hoen, 'Crisis in Eastern Europe: The Downside of a Market Economy Revealed?', European Review, Vol. 19, No. 1 (2011), p. 31, at <http://dx.doi.org/10.1017/S1062798710000347> the Central and Eastern European countries decided to implement a market economy embedded in a democratic order. A constituent element of the transition was a fully-fledged integration with the global economy. One of the consequences of this integration is that the countries are now severely hit by the financial crisis. Until recently, however, it all looked flourishing and economic growth figures indicated a steady catch up with average welfare levels in the European Union (EU 
ly negative, while Estonia is the only country in the CEE group where the situation of national economy is actually more positively evaluated than that of the European level.

Figure 3. Negative perceptions of national and European economy (2011)

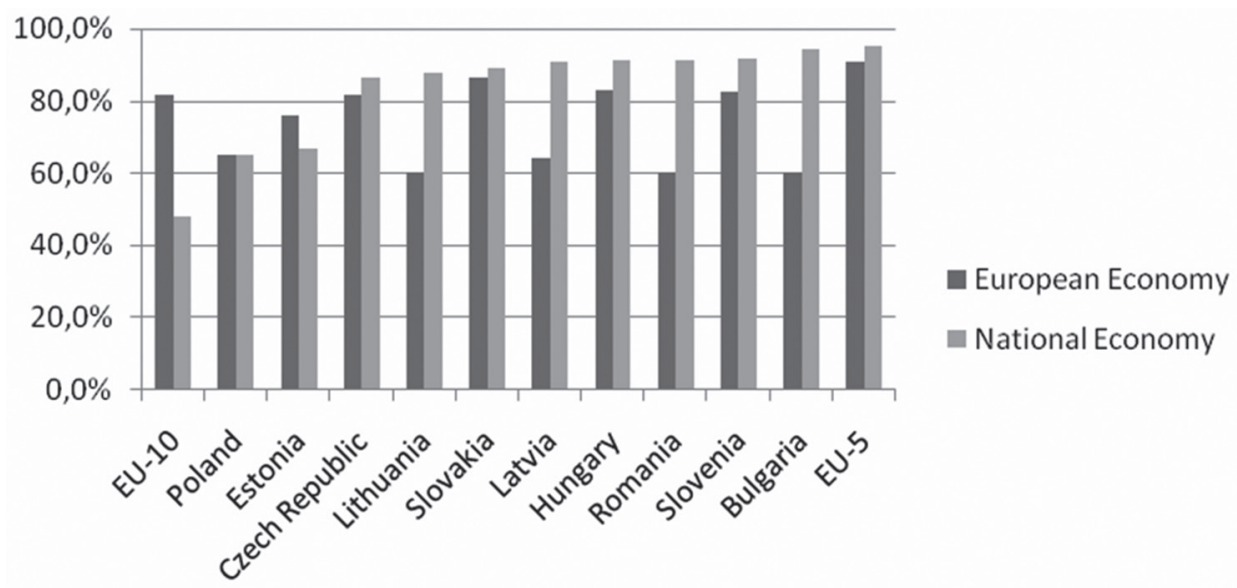

Data: EB 2011. Note: countries are ordered according to the negative evaluation of national economy.

Having analyzed the overall impact of the economic and financial crisis in CEE countries in terms of basic macroeconomic indicators and public opinion perceptions, we can now turn to analyzing the changes in political trust in the same period. In the following figures we can assess the way national and supranational institutional trust has changed at three important time points over the past decade. As the dependent variable is dichotomous and we cannot really evaluate the intensity of trust, for the sake of clarity, the values in the graphs correspond to the evolution of net trust in institutions. ${ }^{43}$ This is the percentage of respondents that declare to trust the institution minus the percentage of those who indicate that they tend not to trust it. In this way we can see more clearly whether those who trust outnumber those who do not feel confident about the institution in question (if the number is positive), or on the contrary, whether those distrusting prevail (if the percentage is negative). The results for the three groups of countries are presented in Figure 4 and the detailed data regarding country-level change in trust are included in the annex to this article (Table 3 ).

We first turn to the higher level - the supranational level of EU institutions and its development in the wake of the economic and financial crisis. The institutions of the $\mathrm{EU}$ are far more remote than the national institutions, and thus, are less known by the citizens and not so easily distinguished from each other. That is why we chose to focus on the more generic measure of trust at the supranational level: trust in EU as an in-

43 F. Roth, The Eurozone Crisis and Its Effects on Citizens' Trust in National Parliaments, CEPS Working Papers, 8 December 2010, at <https://www.ceps.eu/system/files/book/2010/12/Effect\%20of\%20 the $\% 20$ crisis\%20on\%20trust.pdf $>$. 
stitution, rather than the variables related to specific institutions of the EU. However, trends in trust towards each EU institution (the European Commission, the European Parliament, and the European Council) have been also analyzed confirming that the aggregate levels of trust follow the same patterns for the years and country groups under scrutiny here.

Figure 4. Net institutional trust (2004-2011)
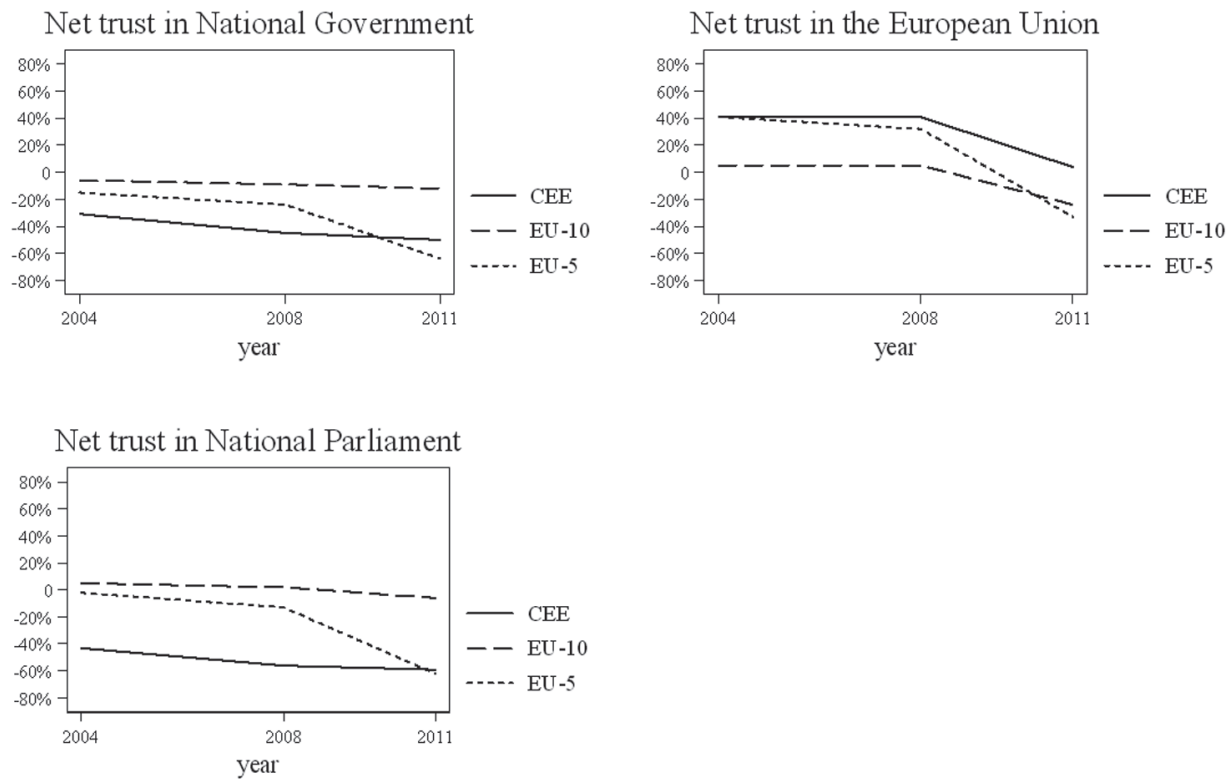

Data: EB 62 (2004), EB 69.2 (2008), EB 76.3 (2011).

At the supranational level, it is quite clear that while the net levels of trust between 2004 and 2008 remain almost the same, there is a very clear downward trend in 2011 for all three groups of countries. The decrease is especially pronounced in the case of the five countries affected most severely by the economic and financial crisis (EU-5). However, the aggregate change of mood in Central Eastern European member states is quite clear. While these countries have not been affected as severely by the economic downturn and the associated austerity measures as Southern European states (and Ireland), still citizens in the new member states have become much more distrustful of European institutions in 2011, as compared to 2008, before the economic crisis became an issue. However, while in all old member states of the EU those who lack confidence in the EU outnumber those who admit to trust it, the CEE countries remain above the level of zero net trust, that is, there are still more citizens who trust the EU on the aggregate level of the region.

The other element of interest here is trust in national institutions in the same period. As mentioned in the beginning, overall levels of trust in national institutions in the CEE countries at the moment of accession have been much lower than in the rest of the 
EU, while trust in European institutions was rather high. When looking at the results of trust in national institutions: government and parliament, it becomes clear that the general tendency to distrust national institutions among CEE member states of the EU has not changed over the course of the years of their EU membership and it has become slightly stronger after 2008.

We can also observe that there is a clear downward trend in the old member states of the periphery (EU-5): in 2011 the levels of net trust in national institutions in these countries were even lower than in Central Eastern Europe. Therefore, we can conclude that, as expected, it is in these countries most hardly hit by the economic and financial crisis and the austerity measures implemented to tackle it where citizens withdraw their trust in national institutions, while in Central Eastern Europe we observe only a slightly negative trend.

\section{EXPLAINING TRUST IN NATIONAL INSTITUTIONS IN CENTRAL EASTERN EUROPE IN THE CONTEXT OF EUROPEAN ECONOMIC AND FINANCIAL CRISIS}

In order to verify our hypotheses regarding political trust in Central Eastern Europe in relation to the perceptions of the economic crisis and the EU we have performed a set of logistic regressions. The overall aim is to establish whether perceptions related to the economic and political crisis can constitute predictors for European and national political trust. In order to do that we have included factors related to the attitudes regarding national and European economy in the models, as well as the deteriorating perceptions of the EU.

The dependent variables are the trust in national parliament and trust in the EU. Trust in national parliament has been chosen as the variable which best reflects the levels of political trust in the domestic context, as the parliament constitutes the cornerstone of democracy in its function of political representation and might be less influenced by partisan preferences and electoral evaluations as is the case of trust in national government. ${ }^{44}$ Trust in the supranational institutional level is operationalized with the variable denoting trust in the EU as an institution. Trust in both cases is a binary variable coded "tend not to trust" (0) and "tend to trust" (1). As mentioned above, such a formulation imposes some restrictions on the way we can interpret the results, above all we are unable to really measure the intensity of political trust. However, for the purpose of this study, this information might be enough as the objective is to establish whether there is any relation between the two levels of governance overall and verify the direction of such possible association.

Independent variables include controls for sex (with women as the reference category), age of the respondent, habitat (rural being the category of reference) and the

44 Unfortunately, the EB does not include questions regarding vote in national elections, therefore, we cannot control for attitudes towards the incumbent government. 
perception of personal economic situation, specifically perception of respondent's job situation coded from good to bad, and therefore reflecting negative perceptions of one's employment situation. Secondly, variables measuring knowledge about the $E U$ and politicization are also introduced, the latter operationalized as discussion of European politics, since we are interested in controlling for the effect of discussing issues related to the performance of the EU. The third set of variables is constituted by negative perceptions of the economy. However, here we include two different variables - one regarding the negative perception of national economy and one which refers to the negative evaluation of the European economic performance. The last block of variables operationalizes perceptions related specifically to institutional performance. In terms of EU political performance, the (deteriorating) EU image is taken into account, on the other, the lack of trust in the EU as an institution. In terms of national political institutions, lack of trust in national parliament is included as a factor. These variables can help us answer the question of how the deterioration of perceptions of political performance of national and European institutions are associated between different levels of government.

Table 1. Logistic regression on trust in the EU in Central Eastern Europe (2011)

\begin{tabular}{|l|c|c|c|}
\hline Independent variable & B & $($ S.E. $)$ & Exp (B) \\
\hline Sex (Woman) & -.025 & & .975 \\
\hline Age & $-.063^{* * *}$ & $(.020)$ & .939 \\
\hline Habitat (Rural) & -.092 & $(.063)$ & .912 \\
\hline Employment situation (Bad) & $-.244^{* * *}$ & $(.040)$ & .784 \\
\hline EU knowledge & $.158^{*}$ & $(.071)$ & 1.171 \\
\hline European politics discussion & .035 & $(.097)$ & 1.036 \\
\hline National economy (Bad) & $.119^{*}$ & $(.053)$ & 1.127 \\
\hline European economy (Bad) & $-.815^{* * *}$ & $(.053)$ & .443 \\
\hline Trust national parliament (No trust) & $-2.135^{* * *}$ & $(.093)$ & 8.454 \\
\hline Country dummies: & B & $($ S.E.) & Exp (B) \\
\hline Czech Republic & $-.600^{* * *}$ & $(.131)$ & .549 \\
\hline Estonia & $-.679^{* * *}$ & $(.148)$ & .507 \\
\hline Hungary & $-.320^{*}$ & $(.134)$ & .726 \\
\hline Latvia & $-.806^{* * *}$ & $(.130)$ & .447 \\
\hline Poland & $-.642^{* * *}$ & $(.134)$ & .526 \\
\hline Slovakia & -.214 & $(.131)$ & .807 \\
\hline Slovenia & $-.597^{* * *}$ & $(.128)$ & .551 \\
\hline Bulgaria & $.519^{* * *}$ & $(.153)$ & 1.680 \\
\hline Romania & .006 & $(.146)$ & 1.006 \\
\hline
\end{tabular}




\begin{tabular}{|l|c|c|c|}
\hline Model summary & B & (S.E.) & Exp (B) \\
\hline -2 LL & 6708.884 & \\
\hline Change in 2 LL & 1499.986 & \\
\hline Nagelkerke R2 & 0.298 & \\
\hline \% correct & $70.4 \%$ & \\
\hline N & 5928 & \\
\hline
\end{tabular}

Data: EB 76.3, November 2011. Note: Dependent variable - trust in the European Union, (0) Tend not to trust, (1) Tend to trust. ${ }^{*} \mathrm{p}<.05 ;{ }^{* *} \mathrm{p}<.01 ;{ }^{* * *} \mathrm{p}<.001$

We have first analyzed the effects of our independent variables on trust in the EU as an institution (Table 1). We have observed that in terms of socio-economic variables, age might constitute a predictor of trust to some extent - older citizens in CEE countries have slightly smaller odds of trusting the EU. Also bad employment situation is associated with lower levels of trust in the EU. Knowledge about the EU and Discussion of European politics have no effect on the odds of trusting the EU. It seems therefore that our assumption that more negative reporting on the EU political and economic troubles might cause a politicization of the EU and trigger negative evaluations of its institutions is not confirmed by the data.

Regarding our hypotheses on the effects of perceptions of economic crisis on political trust, we find that when citizens of Central and Eastern European member states perceive their own national economy in negative terms, they are more prone to trust the $\mathrm{EU}$, as stipulated by the performance theory, and thus confirming our H1a. Negative perceptions of the European economy, on the other hand, constitute a good predictor of less trust in the EU, as expected. In terms of how political trust interplays between the national and the European level, in line with the existing research and our expectations, we find that at the individual level there is a congruence process at work and those who mistrust their national parliament, tend to also exhibit lower levels of trust in the EU as part of a more general process of political disaffection. Thus our $\mathrm{H} 2 \mathrm{~b}$ is confirmed.

We now turn to the second model proposed (Table 2), where we test a similar set of independent variables and their association with trust in the national parliaments in CEE countries. Here, socio-economic control variables seem to have little explanatory power. The only exception is personal bad employment situation; as might be expected, it decreases the odds of trusting in national parliament. Knowledge about the EU, on the other hand, is associated with more trust in the national parliament, as well as is the case of discussion of European politics, pointing to a more general positive effect of political knowledge on institutional trust in the region.

As far as the initial hypothesis regarding perceptions of economic performance is concerned, there are two main factors which are good predictors of trust in national parliament across CEE countries. In terms of evaluation of the economy, a negative perception of the national economic situation decreases the odds of political trust in national institutions, in line with the existing research. The other variable of interest, 
related to the evaluation of European economy turns out to be significant as well. The direction of the effect of this variable indicates that negative evaluations of the European economy increase the odds of depositing trust in the national parliament, confirming our hypothesis $\mathrm{H} 1 \mathrm{~b}$. This finding actually might indicate that the financial and economic problems at the European level might result in CEE countries' citizens turning to their national institutions rather than prompting a more general political disaffection at both institutional levels. Nevertheless, in order to be able to ascertain causality from the supranational to the national level cross-sectional analysis is not enough, and the processes at work would require further investigation, ideally with panel data.

The second research hypothesis, regarding the effects of rising Euroscepticism and the perceptions of a declining political performance in the EU after 2008, yields further interesting results. Lack of trust in $E U$ as an institution decreases the odds of trusting in the national parliament among the ten CEE member states, a finding consistent with the congruence argument and in line with our hypothesis $\mathrm{H} 2 \mathrm{~b}$.

Table 2. Logistic regression on trust in National Parliament in Central Eastern Europe (2011)

\begin{tabular}{|l|c|c|c|}
\hline Independent variable: & B & $($ S.E. & Exp (B) \\
\hline Sex (Woman) & -.107 & $(.075)$ & .898 \\
\hline Age & .035 & $(.025)$ & 1.036 \\
\hline Habitat (Rural) & .135 & $(.079)$ & 1.144 \\
\hline Employment situation (Bad) & $-.133^{* * *}$ & $(.053)$ & .875 \\
\hline EU knowledge & $.349^{* * *}$ & $(.085)$ & 1.418 \\
\hline European politics discussion & $.273^{* *}$ & $(.112)$ & 1.314 \\
\hline National economy (Bad) & $-1.034^{* * *}$ & $(.066)$ & .356 \\
\hline European economy (Bad) & $.194^{* *}$ & $(.066)$ & 1.214 \\
\hline Trust EU (No trust) & $-1.882^{* * *}$ & $(.100)$ & .152 \\
\hline Country dummies & & & \\
\hline Czech Republic & $.402^{*}$ & $(.200)$ & 1.496 \\
\hline Estonia & $1.956^{* * *}$ & $(.186)$ & 7.071 \\
\hline Hungary & $1.970^{* * *}$ & $(.180)$ & 7.172 \\
\hline Latvia & $.810^{* * *}$ & $(.192)$ & 2.248 \\
\hline Poland & $.973^{* * *}$ & $(.180)$ & 2.647 \\
\hline Slovakia & $1.378^{* * *}$ & $(.179)$ & 3.967 \\
\hline Slovenia & .368 & $(.203)$ & 1.444 \\
\hline Bulgaria & $1.480^{* * *}$ & $(.186)$ & 4.391 \\
\hline Romania & .375 & $(.216)$ & 1.455 \\
\hline
\end{tabular}




\begin{tabular}{|l|c|c|c|}
\hline Model summary & B & (S.E.) & Exp (B) \\
\hline -2 LL & 4571.228 & \\
\hline Change in -2 LL & 1770.710 & \\
\hline Nagelkerke R2 & .393 & \\
\hline \% correct & $81.6 \%$ & \\
\hline N & 5910 & \\
\hline
\end{tabular}

Data: EB 76.3, November 2011. Note: Dependent variable - trust in the National Parliament, (0) Tend not to trust, (1) Tend to trust. ${ }^{*} \mathrm{p}<.05 ;{ }^{* *} \mathrm{p}<.01 ;{ }^{* * *} \mathrm{p}<.001$

Our results indicate that while negative economic perceptions at the European level correlate with more trust in national institutions indicating compensation, political evaluations point towards congruence of trust. A growing disaffection towards the EU in CEE countries seems to be part of a more generalized disaffection with the political system in the new democracies of Central Eastern Europe.

Overall, the two models confirm our initial hypothesis concerning the effects of political and economic crisis of the EU on political trust in Central Eastern Europe. However, it must be noted that here we focus on performance evaluations and do not take into account affective factors which might be less volatile in the face of the crisis. Another issue is the importance of the contextual factors and the differential impact of the crisis in terms of real economic indicators, across the region. The effects of the latter could only be taken into account in a more complex, multilevel research design.

\section{DISCUSSION}

The main objective of the article is to explore the ways in which institutional trust of citizens from Central Eastern European new member states has been affected by the current financial and economic crisis at the EU level. In a multilevel system of governance, such as the European Union, the national and supranational institutions are weaved together in a dynamic structure. The Eastward enlargement of the EU included ten post-socialist member states where levels of political trust have been significantly lower than in the more established Western democracies. Moreover, the levels of economic development of CEE countries have been (and still are) below that of the old member states of the EU. European integration constituted a guarantee of further economic and democratic change and a benchmark for evaluating institutions of the new democracies. In these new member states, the EU has been perceived positively through its economic and political outputs, and membership has been predominantly conceived as a guarantee for further modernization of institutions and economic development. After less than five years of membership the financial and economic crisis has put into question the output legitimacy of the EU institutions, while the support for 
the European integration project has been eroding in the whole of the EU. Therefore, it can be assumed that in the current context of EU institutional crisis, perceptions of the economic and institutional problems at the European and national level, as well as the declining image of the EU, could have an impact on attitudes towards political institutions in these countries.

One hypothesis could be that citizens of the new member states who have become more realistic about the workings of the EU no longer perceive it as the solution to their problems and turn to their national institutions. However, it is also possible that if the national political institutions are perceived as part of the bigger supranational system of decision-making, citizens might feel excluded and, thus, loose trust in both levels of governance. In order to test both possibilities we present a comparative study of the patterns of trust in European and national institutions in the new member states of the EU and propose some basic explanatory models. In terms of descriptive analysis, we observe that while trust in the EU has been declining in all of the CEE countries and the share of Eurosceptic citizens is growing, there are no such clear trends at the national level.

Regarding the issue of whether the perceptions of economic and political crisis at the European and national level could constitute a determinant of trust in political institutions, iit turns out that in the context of Central Eastern Europe - as expected - negative perceptions of national economy continue to constitute a good predictor of more trust in the EU, while negative perception of European economy increase the odds of trusting in national parliament. The latter finding is especially significant as it points to the ways in which both levels of governance are weaved into a dynamic structure. The second question posed in the paper refers to negative perceptions of national political performance and falling levels of trust in European institutions. Here it becomes quite clear that a congruence process is at work in the context of Central Eastern Europe, and a lack of trust and a negative image of the EU increase the odds of not trusting the domestic institutions, indicating a more general tendency of political disaffection.

These are only preliminary findings concerning the impact of the perceptions of financial and economic crisis on political trust in Central and Eastern European EU member states. We can only start to assess the impact of the economic and financial crisis on levels of political trust in the context of the EU as a political system. The data on institutional trust used in this article comes from 2011, while in the context of the EU most pronounced effects of the Eurocrisis and institutional efforts to tackle it were developed mostly in 2011 and 2012, with the controversies surrounding the second and third Greek bailout, Spanish and Italian sovereign debt problems, and the establishment of the European Stability Mechanism, as some of the more recent elements of the Eurozone crisis. Therefore, this impact will be better evaluated in the upcoming years, as it is to be seen how the austerity politics undertaken in the name of the EU influence further European and domestic political trust in the European political system. 
Table 3. Trust in Central Eastern European countries compared (2011)

\begin{tabular}{|c|c|c|c|c|c|c|}
\hline \multirow[b]{2}{*}{ Slovenia } & \multicolumn{2}{|c|}{$\begin{array}{c}\text { Tend to trust } \\
\text { National Parliament }\end{array}$} & \multicolumn{2}{|c|}{$\begin{array}{c}\text { Tend to trust } \\
\text { National Government }\end{array}$} & \multicolumn{2}{|c|}{$\begin{array}{l}\text { Tend to trust } \\
\text { the EU }\end{array}$} \\
\hline & $9,2 \%$ & -- & $12,3 \%$ & -- & $40,4 \%$ & -- \\
\hline Romania & $10,2 \%$ & -- & $10,6 \%$ & -- & $56,7 \%$ & -- \\
\hline Slovakia & $25,5 \%$ & -- & $21,6 \%$ & -- & $50,4 \%$ & -- \\
\hline Czech Republic & $10,7 \%$ & - & $15,1 \%$ & - & $39,9 \%$ & -- \\
\hline Lithuania & $11,2 \%$ & $=$ & $18,8 \%$ & $=$ & $58,4 \%$ & -- \\
\hline Estonia & $39,8 \%$ & $=$ & $50,4 \%$ & - & $55,9 \%$ & -- \\
\hline Latvia & $15,2 \%$ & + & $19,9 \%$ & $=$ & $43,6 \%$ & -- \\
\hline Poland & $27,2 \%$ & ++ & $30,5 \%$ & $=$ & $52,2 \%$ & - \\
\hline Hungary & $29,5 \%$ & ++ & $27,2 \%$ & ++ & $50,9 \%$ & - \\
\hline Bulgaria & $27,4 \%$ & ++ & $41,7 \%$ & ++ & $72,0 \%$ & - \\
\hline EU-5 & $18,8 \%$ & -- & $17,7 \%$ & -- & $33,4 \%$ & --- \\
\hline EU-10 & $48,5 \%$ & - & $41,6 \%$ & - & $39,4 \%$ & -- \\
\hline
\end{tabular}

Data: EB69 (2008), EB76 (2011). Questions: I would like to ask you a question about how much trust you have in certain institutions. For each of the following institutions, please tell me if you tend to trust it or tend not to trust it. National Parliament, National Government, European Union. Percentage of "tend to trust". DK treated as missing values. Note: Results for autumn 2011 with change indicated as compared to spring 2008. Change ---/ +++ more than $25 \%,--/++$ more than $10 \%,-/+$ less than $10 \%$. All change statistically significant at .05 level except for $=$ (no statistically significant change $)$.

Table 4. The codification of variables for the logistic regression models

\begin{tabular}{|c|c|}
\hline \multicolumn{2}{|l|}{ Dependent } \\
\hline Trust National Parliament & 0 - Tend not to trust, 1 - Tend to trust \\
\hline Trust the EU & 0 - Tend not to trust, 1 - Tend to trust \\
\hline \multicolumn{2}{|l|}{ Independent } \\
\hline Sex & 0 - Male, 1 - Female \\
\hline Age & $1-15-24,2-25-34,3-35-44,4-45-54,5-55-64,6-65+$ \\
\hline Habitat & 0 - Town/City, 1 - Rural/Village \\
\hline Employment situation & 1 - Very Good, 2 - Rather Good, 3 - Rather Bad, 4 - Very Bad \\
\hline European politics discussion & 1 - Frequently, 0 - Occasionally/Never \\
\hline EU Knowledge & 1 - Good, 0 - Bad \\
\hline Situation of National Economy & 1 - Very Good, 2 - Rather Good, 3 - Rather Bad, 4 - Very Bad \\
\hline Situation of European Economy & 1 - Very Good, 2 - Rather Good, 3 - Rather Bad, 4 - Very Bad \\
\hline Distrust EU & 0 - Tend to trust, 1 - Tend not to trust \\
\hline Distrust the National Parliament & 0 - Tend to trust, 1 - Tend not to trust \\
\hline
\end{tabular}




\section{BIBLIOGRAPHY}

Anderson Ch.J., 'When in Doubt, Use Proxies: Attitudes toward Domestic Politics and Support for European Integration', Comparative Political Studies, Vol. 31, No. 5 (1998), at <http:// dx.doi.org/10.1177/0010414098031005002>.

Cerutti F., Lucarelli S. (eds.), The Search for a European Identity. Values, Policies and Legitimacy of the European Union, New York 2008 (Routledge/Garnet Series. Europe in the World, 2).

Connolly R., 'The Determinants of the Economic Crisis in Post-Socialist Europe', Europe-Asia Studies, Vol. 64, No. 1 (2012), at <http://dx.doi.org/10.1080/09668136.2012.635474>.

Demetriou K.N. (ed.), The European Union in Crisis. Explorations in Representation and Democratic Legitimacy, Cham 2014.

Duchesne S., Frognier A.-P., 'National and European Identifications: A Dual Relationship', Comparative European Politics, Vol. 6, No. 2 (2008), at <http://dx.doi.org/10.1057/palgrave.cep.6110128>.

Easton D., A Systems Analysis of Political Life, Chicago 1979 (Political Theory, 833).

Fuchs D., 'European Identity and Support for European Integration' in S. Lucarelli, F. Cerutti, V.A. Schmidt (eds.), Debating Political Identity and Legitimacy in the European Union, Abingdon-New York 2011 (Routledge/Garnet Series. Europe in the World, 11).

Fuchs D., Klingeman H.-D., 'Democratic Communities in Europe. A Comparison between East and West' in H.-D. Klingemann, D. Fuchs, J. Zielonka (eds.), Democracy and Political Culture in Eastern Europe, London 2006 (Routledge Research in Comparative Politics, 15).

Fuchs D., Klingeman H.-D. (eds.), Cultural Diversity, European Identity and the Legitimacy of the EU, Cheltenham 2011 (Studies in EU Reform and Enlargement).

Gabel M., 'Public Support for European Integration: An Empirical Test of Five Theories', The Journal of Politics, Vol. 60, No. 2 (1998).

Garry J., Tilley J, 'Public Support for Integration in the Newly Enlarged EU: Exploring Differences Between Former Communist Countries and Established Member States' in M. Marsh, S. Mikhaylov, H. Schmitt (eds.), European Elections after Eastern Enlargement. Preliminary Results from the European Election Study 2004, Mannheim 2007 (CONNEX Raport Series, 01).

Guerra S., 'Does Familiarity Breed Contempt? Determinants of Public Support for European Integration and Opposition to It before and after Accession', Journal of Common Market Studies, Vol. 51, No. 1 (2013), at <http://dx.doi.org/10.1111/j.1468-5965.2012.02300.x>.

Hix S., Høyland B., The Political System of the European Union, Basingstoke 2011 (The European Union Series).

Hoen H.W., 'Crisis in Eastern Europe: The Downside of a Market Economy Revealed?', European Review, Vol. 19, No. 1 (2011), at <http://dx.doi.org/10.1017/S1062798710000347>.

Hooghe L., Marks G., 'Calculation, Community and Cues: Public Opinion on European Integration', European Union Politics, Vol. 6, No. 4 (2005), at <http://dx.doi. org/10.1177/1465116505057816>.

Ilonszki G., 'National Discontent and EU Support in Central and Eastern Europe', Europe-Asia Studies, Vol. 61, No. 6 (2009), at <http://dx.doi.org/10.1080/09668130903063591>. 
Inglehart R., 'Cognitive Mobilization and European Identity', Comparative Politics, Vol. 3, No. 1 (1970), at <http://dx.doi.org/10.2307/421501>.

Jackson J.E., Mach B.W., Miller-Gonzalez J.L., 'Buying Support and Regime Change: The Evolution of Polish Attitudes towards the EU and Voting between Accession and 2008', European Union Politics, Vol. 12, No. 2 (2011), at <http://dx.doi.org/10.1177/1465116511400197>. Linz J.J., Stepan A.C., Problems of Democratic Transition and Consolidation. Southern Europe, South America, and Post-Communist Europe, Baltimore 1996.

Loveless M., 'Agreeing in Principle: Utilitarianism and Economic Values as Support for the European Union in Central and Eastern Europe', Journal of Common Market Studies, Vol. 48, No. 4 (2010), at <http://dx.doi.org/10.1111/j.1468-5965.2010.02088.x>.

Lucarelli S., Cerutti F., Schmidt V.A. (eds.), Debating Political Identity and Legitimacy in the European Union, Abingdon-New York 2011 (Routledge/Garnet Series. Europe in the World, 11)

Mach Z., Pożarlik G., Collective Identity Formation in the Process of EU Enlargement. Defeating the Inclusive Paradigm of a European Democracy?, Oslo 2008 (RECON Online Working Paper, 14).

McLaren L.M., Identity, Interests, and Attitudes to European Integration, Basingstoke 2006 (Palgrave Studies in European Union Politics).

Mishler W., Rose R., 'Trust, Distrust and Skepticism: Popular Evaluations of Civil and Political Institutions in Post-Communist Societies', The Journal of Politics, Vol. 59, No. 2 (1997), at <http://dx.doi.org/10.2307/2998171>.

Mishler W., Rose R., 'What Are the Origins of Political Trust?: Testing Institutional and Cultural Theories in Post-Communist Societies', Comparative Political Studies, Vol. 34, No. 1 (2001), at <http://dx.doi.org/10.1177/0010414001034001002>.

Muñoz J., Torcal M., Bonet E., 'Institutional Trust and Multilevel Government in the European Union: Congruence or Compensation?', European Union Politics, Vol. 12, No. 4 (2011), at <http://dx.doi.org/10.1177/1465116511419250>.

Offe C., The Varieties of Transition. The East European and East German Experience, Oxford 1996. Pridham G., 'Legitimating European Union Accession? Political Elites and Public Opinion in Latvia, 2003-2004', Party Politics, Vol. 13, No. 5 (2007), at <http://dx.doi. org/10.1177/1354068807080086>.

Ramet S. (ed.), Central and Southeast European Politics since 1989, Cambridge-New York 2010. Roth F., The Eurozone Crisis and Its Effects on Citizens' Trust in National Parliaments, CEPS Working Papers, 8 December 2010, at <https://www.ceps.eu/system/files/book/2010/12/ Effect\%20of\%20the\%20crisis\%20on\%20trust.pdf $>$.

Sánchez-Cuenca I., 'The Political Basis of Support for European Integration', European Union Politics, Vol. 1, No. 2 (2000), at <http://dx.doi.org/10.1177/1465116500001002001>.

Schmidt V.A., 'The Problems of Identity and Legitimacy in the European Union. Is More Politics the Answer?' in S. Lucarelli, F. Cerutti, V.A. Schmidt (eds.), Debating Political Identity and Legitimacy in the European Union, Abingdon-New York 2011 (Routledge/Garnet Series. Europe in the World, 11).

Scicluna N., 'Domestication of the Euro Crisis: Legal and Political Manifestations of Euroscepticism in Germany', Journal of Contemporary European Research, Vol. 10, No. 3 (2014), at <http://www.jcer.net/index.php/jcer/article/view/621>. 
Serricchio F., Tsakatika M., Quaglia L., 'Euroscepticism and the Global Financial Crisis', Journal of Common Market Studies, Vol. 51, No. 1 (2013), at <http://dx.do.org/10.1111/ j.1468-5965.2012.02299.x>.

'Slovakia's Revolt against Solidarity', The Economist, 14 August 2010, at <http://www.economist.com/blogs/easternapproaches/2010/08/slovakia_and_greece>.

Vachudová M.A., Europe Undivided. Democracy, Leverage, and Integration after Communism, Oxford 2005.

White S., Batt J., Lewis P.G. (eds.), Developments in Central and East European Politics, 5, Basingstoke 2013.

Aleksandra SOJKA is a postdoctoral fellow at the Department of Political Science of the University of Granada in Spain. Her principal research interests are in the area of EU politics, comparative European politics, as well as political sociology of Europe. She focuses on attitudes towards European Union in Central and Eastern Europe and explores the role of public opinion and elite positions in the process of European integration. Her research appeared in Revista Española de Ciencia Política and as chapters in several edited books. 